\begin{tabular}{|l|l|l|l|l|l|} 
J. Tek. Ling & Vol.11 & No.3 & Hal. 435 - 441 & Jakarta, September 2010 & ISSN 1441-318X \\
\hline
\end{tabular}

\title{
PENDAYAGUNAAN DUA JENIS ZINGIBERACEAE [C. mangga (temu mangga) dan $K$. angustifolia (kunci menir)] SEBAGAI SUMBER BAHAN IMUNOMODULATOR SECARA IN VITRO
}

\author{
Praptiwi dan Chairul \\ Peneliti di Bidang Botani \\ Lembaga IImu Pengetahuan Indonesia
}

\begin{abstract}
Observation of imunomodulation properties of methanol extract derive (hexane, ethyl acetate, methanol/water) of Curcuma mangga (temu mangga) and Kaempferia angustifolia (kunci menir) had been carried out by in vitro assay. It was done by determining the phagocytised activity and capacity of macrophage cells of mice (Mus musculus) peritonium inducted with Staphyllococcus epidermidis. The result showed that each fraction had different phagocytised activity and capacity. Almost all of the fractions tested improved the activity (50-96\%) and capacity macrophage cells phagocytised compared to negative control (52 dan 502) and positive control (97 dan 1076). The positive control was 1000 ug Stimuno (Phyllanthus niruri extract), while the negative control was aquadest. The ethyl acetate fraction of Z. cassumunar (bangle) had highest phagocytised activity and capacity followed by C. mangga (temu mangga) and $\mathrm{K}$. Angustifolia (kunci menir). It can be concluded that there were significant differences of phagocytised activity and capacity among fraction tested.
\end{abstract}

Keywords : Zingiberaceae, Curcuma mangga, Kaempferia rotunda, Zingiber cassumunar, immunomodulator, phagocytised, macrophage cells.

\section{PENDAHULUAN}

\subsection{Latar Belakang}

Indonesia saat ini merupakan laboratorium penyakit terlengkap, berbagai penyakit muncul ke permukaan, mulai dari penyakit infeksi, penyakit degeneratif dan penyakit baru semacam campak Jerman, sindrom pernafasan akut parah (SARS) ${ }^{1)}$. Kesehatan merupakan unsur utama pembangunan sumber daya manusia (SDM), dan sudah saatnya pembangunan dilihat dari kualitas SDMnya. Kesehatan masyarakat tidak hanya terdiri dari pengobatan penyakit yang dilakukan dalam waktu singkat tetapi juga upaya kesehatan jangka menengah dan jangka panjang ${ }^{2)}$.

Salah satu bidang baru dalam farmakologi yang masih dalam tingkat eksplorasi dan perdebatan adalah Imunomodulator (Immunomodulating agents) yaitu mengembangkan bahanbahan yang dapat meningkatkan respon imunitas daripada menekannya, atau dengan kata lain imunomodulator adalah bahan (obat) yang dapat mengembalikan ketidakseimbangan sistem imun. Cara kerja imunomodulator meliputi : 1) mengembalikan fungsi sistem imun yang terganggu (imunrestorasi), 2) memperbaiki fungsi sitem imun (imunostimulasi) dan 3) 
menekan respons imun (imunosupresi). Imunomodulator digunakan terutama pada penyakit imunodefisiensi, infeksi kronis dan kanker. Pemberian imunostimulan atau imunomodulator sangat diperlukan untuk mencegah penghancuran sel penolong CD4+ pada pasien AIDS dan kanker ${ }^{3}$. Dalam ilmu kedokteran, imunitas pada mulanya berarti resistensi relatif terhadap suatu mikroorganisme. Resistensi terbentuk berdasarkan respon imunologik. Selain membentuk resistensi terhadap suatu infeksi, respon imun juga dapat mengakibatkan terjadinya berbagai penyakit. Oleh karena itu pada masa sekarang ini arti respon imun sudah lebih luas, yang pada dasarnya mencakup pengobatan maupun pencegahan suatu penyakit yang disebabkan oleh pengaruh faktor dari luar tubuh atau zat asing. Aktivitas sistem imun dapat menurun karena berbagai faktor, diantaranya karena usia atau penyakit ${ }^{4,5,6)}$. Adanya senyawasenyawa kimia yang dapat meningkatkan aktivitas sistem imun sangat membantu untuk mengatasi penurunan sistem imun dan senyawa-senyawa tersebut dapat diperoleh dari tumbuh-tumbuhan. Saat ini terdapat beberapa jenis tumbuhan yang dideteksi berkhasiat sebagai imunomodulator, antara lain : Echinacea angustifolia, Andrographis paniculata, Plantago major, Allium sativum, Zingiber officinalis, Curcuma xanthorriza dll. ${ }^{7,8}$. Empon-empon atau temu-temuan (Zingiberaceae) merupakan rempah dan bahan obat tradisional yang penting bagi bangsa Indonesia dan telah menjadi bagian dari budaya bangsa. Oleh karena itu perlu diperhatikan dan dikembangkan serta digali potensinya sehingga memberikan nilai tambah dan dapat meningkatkan nilai jualnya baik dipasar domestik maupun global. Ekspor jahe Indonesia setiap tahunnya sekitar 2 - 4 $\%$ kebutuhan dunia sedang kebutuhan dalam negeri juga tidak sedikit.

Temu-temuan (empon-empon) sudah tidak asing lagi bagi masyarakat Indonesia dan digunakan dalam berbagai ramuan obat tradisional. Sebagian besar dari jenis temu-temuan tersebut adalah suku (marga) Alpinia, Amomum, Curcuma, Kaempferia, Languas dan Zingiber. Jenis-jenis dari suku tersebut sangat mudah diperoleh dan budidayanya tidak terlalu sulit serta teknologinya telah dikuasai. Uji aktivitas dan kapasitas fagositosis ekstrak beberapa jenis temu-temuan dengan pelarut alkohol dan air telah dilakukan. Pada penelitian ini dilakukan uji aktivitas dan kapasitas fagositosis fraksifraksi turunan ekstrak metanol (heksana, etil asetat dan sisa atau metanol/air) dari tiga jenis Zingiber yaitu, C. mangga (temu mangga) dan $K$. angustifolia (kunci menir).

\subsection{Tujuan Penelitian}

Berdasarkan hal tersebut diatas maka penelitian ini bertujuan untuk menggali potensi sumber daya nabati Indonesia (bio-prospecting) sebagai imunomudulator, mencari obat pengganti (alternatif) untuk meningkatkan imunitas penderita penyakit kanker dan AIDS, menyediaan bahan baku obat alternatif untuk sediaan fitofarmaka bagi penyakit kanker, AIDS dan penyakit kronis lainnya.

\section{METODOLOGI}

\subsection{Tempat dan Waktu Penelitian}

Penelitian dilakukan di laboratorium Bahan Alam, Bidang Botani, Pusat Penelitian Biologi LIPI, Cibinong Science Center pada bulan Januari - Juni 2007.

\subsection{Bahan Penelitian}

Bahan yang digunakan pada penelitian antara lain: C. mangga (temu mangga) dan $K$. angustifolia (kunci menir). Pelarut yang digunakan adalah metanol, etil asetat, dan air. Hewan coba adalah mencit putih (Mus musculus) galur Swis Webster (jantan), dan suspensi bakteri uji Staphylococcus epidermidis, PBS (larutan fisiologis), Metanol p.a, EDTA 0,2 M (anti koagulan), dan Giemsa untuk pewarnaan. 


\subsection{Pembuatan ektrak jenis-jenis Zingiberaceae.}

Timbang 100 gram simplisia dari masing-masing jenis, kemudian diekstraksi dengan $\mathrm{MeOH} 95$ \%. Filtrat ditampung dan dipekatkan dengan rotary-evaporator kemudian dikeringkan sampai mencapai bobot tetap. Ekstrak metanol selanjutnya difraksinasi berturut-turut dengan $n$-heksana selanjutnya dengan etil asetat. Masing-masing fraksi yang diperoleh dipekatkan dengan rotary-evaporator hingga diperoleh ekstrak kental.

\subsection{Preparasi ekstrak uji}

Masing-masing ekstrak yang telah dibuat dilarutkan dalam air suling steril dengan variasi konsentrasi logaritma 0,1 sampai dengan $1000 \mu \mathrm{g}$ (ppm) dan untuk meningkatkan kelarutan tambahkan beberapa tetes DMSO. Masing-masing ekstrak uji disiapkan sebanyak $200 \mu$ l untuk pengujian imunomodulator.

\subsection{Preparasi suspensi bakteri uji}

Inokulum Staphyllococcus epidermidis yang telah diinkubasi selama 24 jam, disentrifus dan dipisahkan pelet dan supernatannya. Pada pelet ditambahkan Phosphat Buffer Saline (PBS) steril lalu disetarakan dengan larutan $\mathrm{BaSO}_{4} 10 \%$ pada panjang gelombang $620 \mathrm{~nm}\left(\mathrm{BaSO}_{4} 10 \%\right.$ $10^{9}$ bakteri $\left.10 \% \mathrm{~T}\right)$

\subsection{Preparasi suspensi sel makrofag}

Mencit dimatikan dengan eter, kemudian dibedah. Cairan peritonial pada bagian abdomen diambil dengan menggunakan pipet Eppendrof kemudian tambahkan PBS untuk isotonis.

\subsection{Uji Imunomodulator}

Pada uji imunomodilator, hewan coba dibagi menjadi 3 kelompok dimana sel makrofag dari setiap kelompok uji ditantang dengan bakteri Staphyllococcus epidermidis sebagai berikut:

- Kelompok I (kontrol negatif) : $200 \mu$ l suspensi sel makrofag ditambahkan dengan $200 \mu \mathrm{l}$ suspensi bakteri.

- Kelompok II (kontrol positif) : $200 \mu \mathrm{l}$ suspensi sel makrofag ditambahkan $200 \mu \mathrm{l}$ baku pembanding Stimuno (mengandung ekstrak meniran) dan $200 \mu$ l suspensi bakteri.

- Kelompok III (larutan uji) : $200 \mu \mathrm{l}$ suspensi sel makrofag dicampur dengan $200 \mu \mathrm{l}$ larutan ekstrak uji yang telah disiapkan dan $200 \mu \mathrm{l}$ suspensi bakteri.

\subsection{Preparasi sediaan apus.}

Preparat apus dibuat dengan cara $1-2$ tetes suspensi hasil penantangan sel makrofag dengan bakteri diteteskan diatas kaca objek, kemudian dengan bantuan kaca objek lainnya dihapuskan dengan perlahanlahan sehingga diperoleh hapusan yang rata. Kemudian di fiksasi dengan $\mathrm{MeOH}$ selama 15 menit selanjutnya diwarnai dengan larutan Giemsa $10 \%$ lebih kurang 30 menit. Hasilnya diamati dibawah mikroskop fase kontras dengan perbesaran 1000 kali.

\subsection{Menghitung aktivitas dan kapasitas fagositosis.}

Preparat apus dari masing-masing perlakuan dihitung aktivitas fagositosis (SFA) yaitu, jumlah sel makrofag yang memfagositosis sel bakteri dalam 100 sel makrofag dan kapasitas fagositosis yaitu, jumlah sel bakteri yang difagositosis oleh 50 sel makrofag. Hasil yang diperoleh dibandingkan dengan kontrol (-) maupun kontrol (+).

\subsection{Perhitungan statistik}

UjiANOVAdari masing-masing kelompok uji baik aktivitas dan kapasitas fagositosis dari 
variasi konsentrasi logaritma yang diberikan 0,1 - $1000 \mu \mathrm{g}$ maupun terhadap kontrol (-) dan kontrol $(+)$ dengan nilai signifikan $P<0.05$. Analisa data menggunakan SPSS 12.0 yang berdasarkan pada homogenitas dari setiap variabel dan nilai kenormalan dari setiap varian grup diperoleh hasil pengujian dengan nilai homogenitas terdistribusi homogen dan nilai kenormalan terdistribusi normal dapat diketahui.

\section{HASIL DAN PEMBAHASAN}

Hasil uji aktivitas dan kapasitas fagisitosis fraksi turunan dari temu mangga (C. mangga) menunjukkan bahwa fraksi etil asetat dan metanol/air menunjukkan aktivitas yang mendekati kontrol positif. Fraksi etil asetat pada konsentrasi rendah menunjukkan aktivitas yang lebih tinggi dibandingkan kontrol positif dan menurun pada konsentrasi tinggi, sedangkan ratarata kapasitas fagositosis lebih rendah dibandingkan kontrol positif. Dengan kata lain bahwa fraksi etil asetat dan metanol/ air mempunyai aktivitas fagositosis yang tinggi, tetapi kapasitas fagositosisnya rendah (Gambar 1 dan 2).

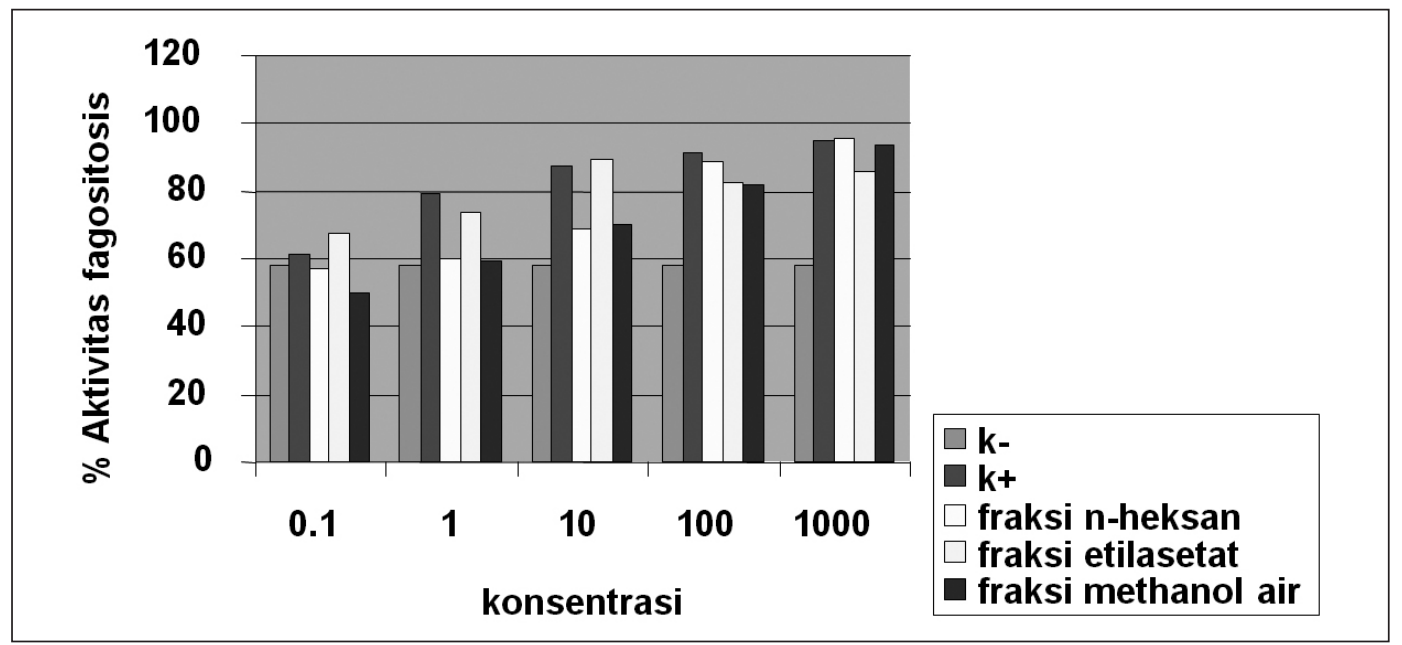

Gambar 1. Diagram Batang \% Aktivitas Fagositosis Fraksi Turunan C. Mangga.

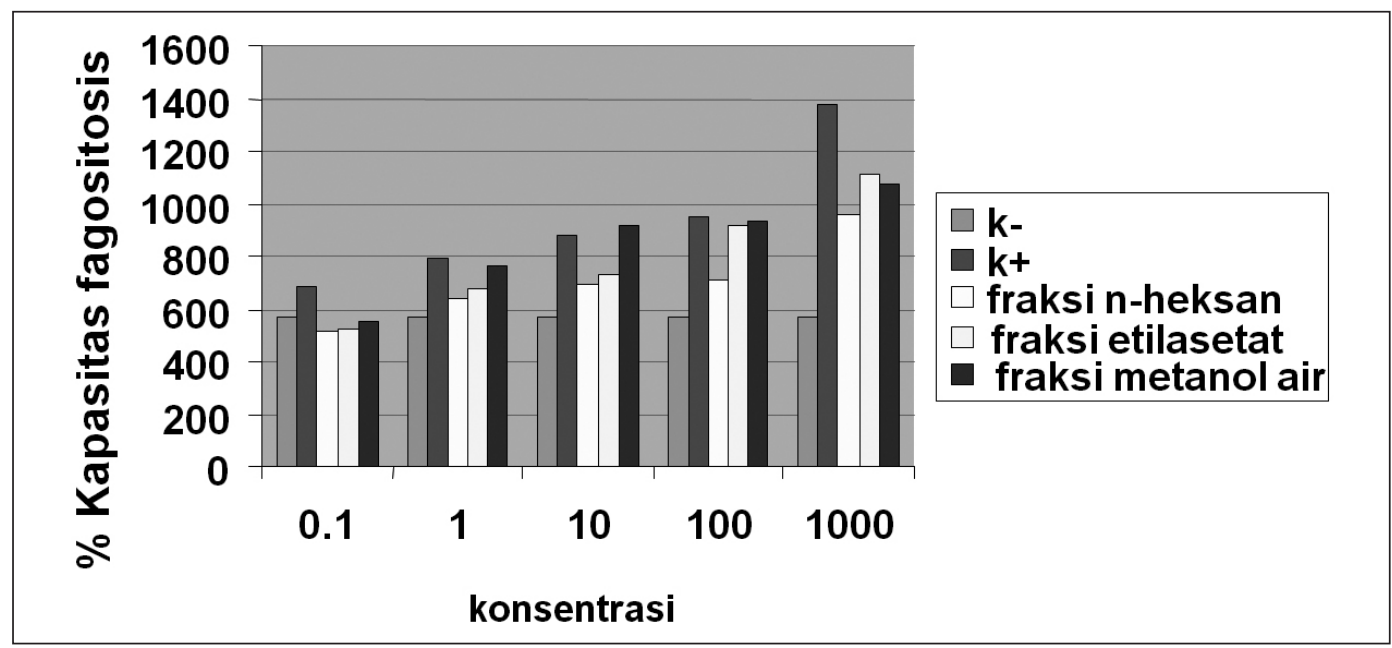

Gambar 2. Diagram Batang \% Kapasitas Fagositosis Fraksi Turunan C. Mangga. 
Hasil menunjukkan bahwa pada fraksi etil asetat pada konsentrasi $10 \mu \mathrm{g}$ memberikan aktivitas fagositosis yang tinggi hampir sama dengan $\mathrm{K}(+)$, tetapi menurun pada konsentrasi yang lebih tinggi 100 dan $1000 \mu \mathrm{g}$, sedangkan kapisitas fagositosisnya meningkat seiring dengan kenaikan konsentrasi dan lebih rendah dari $K(+)$. Jadi pada fraksi etil asetat ini terdapat senyawa kimia yang dapat meningkatkan aktivitas fagositosis sel makrofage pada konsentrasi rendah, tetapi tidak banyak pengaruhnya terhadap kapasitas fagositosis. Hasil uji fagositosis uji aktivitas dan kapasitas fagisitosis fraksi turunan dari $K$. angustifolia (temu kunci) memperlihatkan bahwa aktivitasnya ratarata meningkat seiring dengan kenaikan konsentrasi dan pada konsentrasi $1000 \mu \mathrm{g}$ hampir mendekati kontrol positif baik fraksi heksan, etil asetat maupun metanol/air. Sedangkan kapasitasnya sangat rendah dan pada konsentrasi $1000 \mu \mathrm{g}$ ppm hanya fraksi etil asetatlah yang dapat menyamai kontrol positif (Gambar 3 dan 4).

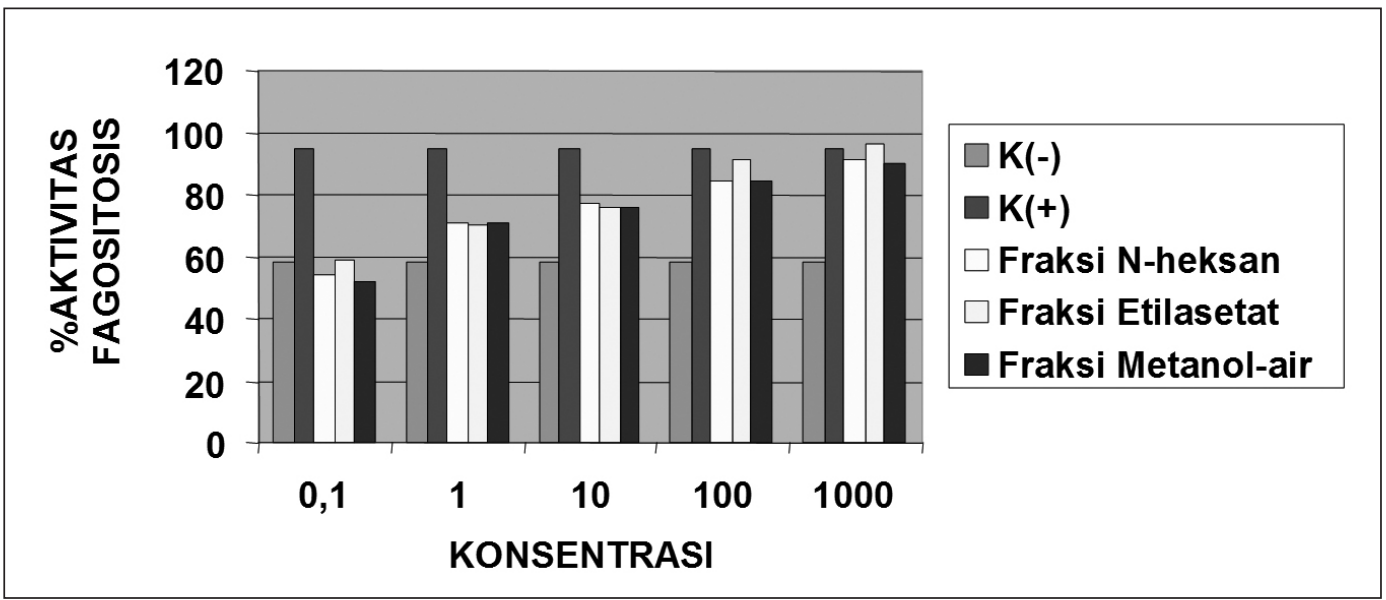

Gambar 3. Diagram Batang \% Aktivitas Fagositosis Fraksi Turunan K. Angustifolia.

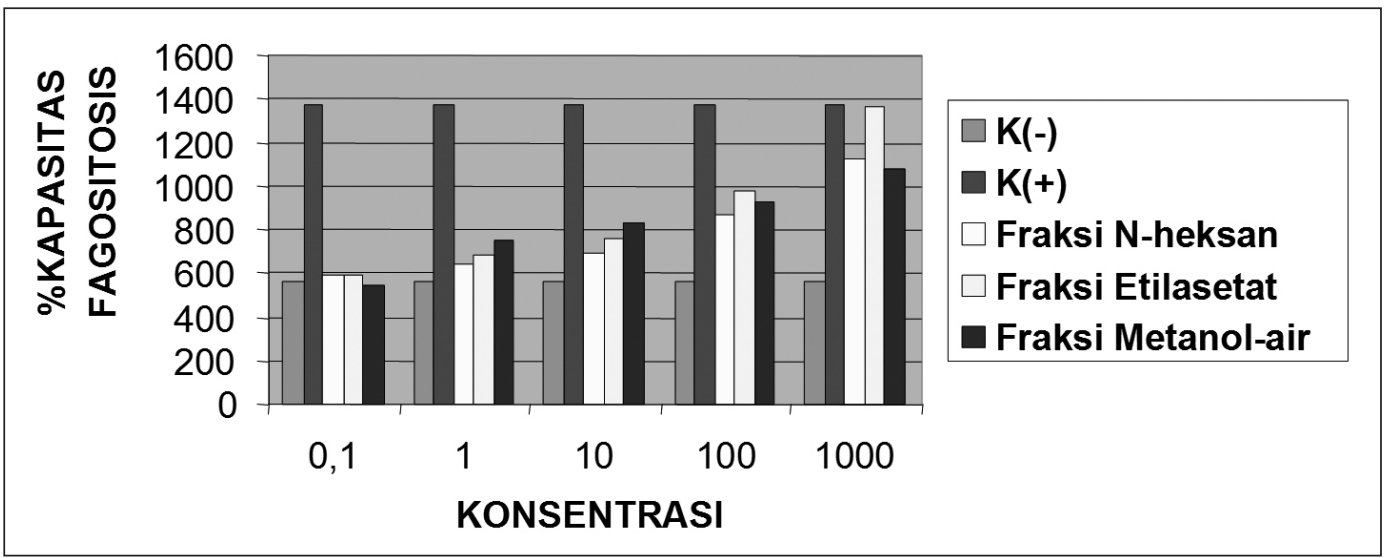

Gambar 4. Diagram Batang \% Kapasitas Fagositosis Fraksi Turunan K. Angustifolia 
Berdasarkan hsil tersebut juga dapat disimpulkan bahwa dari beberapa fraksi turunan $K$. angustifolia (temu kunci) maka fraksi etil asetat yang mempunyai kemampuan meningkatkan sistem imun seperti pada kontrol positif Stimuno.

Berdasarkan pengamatan aktivitas dan kapasitas fagositosis sel makrofag terhadap bakteri S. epidermidis menunjukkan adanya perbedaan jumlah sel makrofag yang memfagositosis bakteri baik ekstrak air maupun ekstrak alkohol $70 \%$ dari masingmasing jenis yang diuji. Skrining aktivitas (SFA) dan kapasitas fagositosik (IF) terhadap ekstrak air dan alkohol secara in-vitro pada variasi dosis logaritma perlakuan $0.1-1000 \mu \mathrm{g}$, pembanding kontrol positif (Stimuno) pada konsentrasi $1000 \mu \mathrm{g}$ (ekstrak Phyllanthus neruri) dan kontrol negatif $\left(\mathrm{H}_{2} \mathrm{O}\right)$. Hasil pengamatan menunjukkan semua jenis temu-temuan yang diuji meningkatkan aktivitas (50 - $96 \%$ ) dan kapasitas (484 958) fagositosis sel makrogfag peritoneum mecit (Mus musculus) yang diinduksi dengan Staphyllococcus epidermidis seiring dengan meningkatnya dosis ektrak.

Aktivitas dan kapasitas fagositosis pada bahan uji berkaitan dengan kandungan kimia yang terdapat dalam bahan uji tersebut. Pada umumnya empon-empon atau temu-temuan (Zingiberaceae) mengandung berbagai komponen kimia penyusun minyak atsirinya (monoterpen dan seskuiterpen) yang umumnya tersari kedalam fraksi heksana, selain itu juga mengandung senyawa lain seperti flavonoid, diterpenoid, fenolik pada fraksi etilasetat, polisakarida ( $\alpha$ - dan $\beta$-glukan)pada fraksi metanol/air. Menurut Inalci et.al.(2005) $)^{9}$, beberapa komponen bioaktif yang berasal dari alam mempunyai efek pleitropik (mempunyai beragam efek fisiologis) dan kombinasi berbagai komponen bioaktif pada satu simplisia atau ekstrak akan memberikan efek sinergis.

Berdasarkan uji statistik dari masingmasing perlakuan memperlihatkan adanya perbedaan yang signifikan baik aktivitas dan kapasitas fagositosis dari variasi konsentrasi yang diberikan maupun terhadap konrol (-) dan kontrol (+). Dari analisa statistik ini dapat disimpulkan bahwa terdapat perbedaan yang bermakna dari aktivitas dan kapasitas fagositosis antar ekstrak yang digunakan dan antar variasi konsentrasi perlakuan. Aktivitas dan kapasitas fagositosis akan meningkat seiring dengan peningkatan konsentrasi yang diberikan, artinya aktivitas dan kapasitas fagositosis berbanding lurus dengan konsentrasi yang diberikan, makin besar konsentrasi yang diberikan makin besar aktivitas dan kapasitas fagositosisnya. Hasil analisa statistik menunjukkan bahwa masing-masing ekstrak yang diberikan memberikan pengaruh yang bermakna $(P \leq 0,05)$ terhadap peningkatan aktivitas dan kapasitas fagositosis sel makrofag. Kemampuan fagositosis sel makrofag dengan parameter sel fagositosit aktif (SFA) yaitu, jumlah sel makrofag an aktif melakukan fagositosis per-100 sel makrofag dan indeks fagositosis (IF) yaitu jumlah rata-rata bakteri yang ditelan oleh satu sel makrofag oleh satu sel makrofag aktif dan dihitung jumlah total bakteri yang ditelan oleh 50 sel makrofag aktif ${ }^{10,11)}$. Menurut Wagner $(1991)^{10)}$, bila nilai SFA dan IF kelompok perlakuan lebih besar dari kelompok kontrol, mengidentifikasikan adanya efek stimulasi atau peningkatan aktivitas fagositosis oleh bahan uji.

Dari semua fraksi turunan yang diuji pada umumnya fraksi etilasetat memperlihatkan terjadi peningkatan aktivitas maupun kapasitas fagositosis sel makrofag hampir sama dengan kontrol positif, terutama K. angustifolia (temu kunci).

\section{KESIMPULAN}

Dari 3 jenis empon-empon yang diuji hampir semua menunjukkan aktivitas dan kapasitas fagositosis tetapi yang terbaik adalah $K$. angustifolia (kunci menir) diikuti oleh C. mangga (temu mangga). Komponen kimia yang bersifat bioaktif pada fraksi etilasetat $K$. angustifolia (kunci menir) perlu diteliti lebih lanjut dengan cara 
mengisolasinya secara kromatografi (KK dan HPLC) dan menentukan struktur kimianya berdasarkan spektra data (UV, IR, MS dan NMR).

\section{DAFTAR PUSTAKA}

1. Anonim. 2005. Indonesia Laboratorium Penyakit Terlengkap, SUARA PEMBANGUNAN, Senin, 13 Juni 2005.

2. Anonim. 2004. Kesehatan Bukan Hanya Pengobatan Penyakit, SUARA PEMBANGUNAN, Jum'at, 29 Oktober 2004.

3. Katzung, B.G 1995. Basic \& Clinical Pharmacology $6^{\text {th }}$ Ed. Prentice-Hall International Inc. 858-878.

4. Nainggolan, N. 1990. Peranan Imunologi dalam bidang kedokteran, Majalah Kedokteran Indonesia, Unversitas Sumatera Utara, Medan; 620-624.
5. Bratawidjaja,K. 2002. Imunologi Dasar, Ed. IV, Fakultas Kedokteran, Universitas Indonesia, Jakarta.

7. Mills, S. aand K Bone. (2000). Principles and Practice of Phytotherapy (Modern Herbal Medicine), Churchill Livingstone Edition.

8. Ebadi, M. 2002. Pharmocodynamic Basis of Herbal Medicine, CRC Press, New York, Washington DC.

9. Inalci, M. et.al. 2005. Use of cancer chemopreventive phytochemicals as Antineoplastic agents, Lanset Oncol. 6; $899-904$.

10. Wagner, H and K. Jurcic. 1991. Assay for immunomodulation and effect on mediators of inflammmation dalam Dey PM and Harborne JB editor. Methods in plants biochemistry; assay for bioactivity, Vol. VI, Academic Press.

11. Ichinose et.al.1998. Enhanchement of phagocytosis in mouse peritoneal macrophages by fragment of acidic fibroblast growth factor ( $\mathrm{aFGF}$ ), Inter. J. Immunopharm. 20, 193-204. 